ELORE (ISSN 1456-3010), vol. 20 - 2/2013.

Julkaisija: Suomen Kansantietouden Tutkijain Seura ry.

[http://www.elore.fi/arkisto/2_13/fingerroos.pdf]

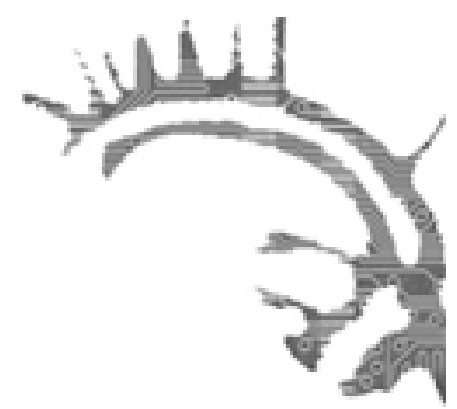

KirJa-ARVio

\title{
MAMMUTTI ITÄMERENSUOMALAISTEN MYTOLOGIASTA
}

\author{
Outi Fingerroos
}

SIIKALA, ANNA-LEENA 2012: Itämerensuomalaisten mytologia. Suomalaisen Kirjallisuuden Seuran Toimituksia 1388 / Tiede. Helsinki: SKS. 536 sivua.

Akateemikko Anna-Leena Siikalan elämäntyön ehkä merkittävin osa-alue on mytologia: sen tutkiminen folkloristina ja uskonnon, erityisesti kansanuskon/kansanuskonnollisuuden tuntijana. Viimeiset laajat mytologian esitykset ovat peräisin 1960-luvulta, joten Siikala on tarttunut Suomen ja lähialueiden suullisen runouden kuvaamien myyttien maailmoihin päivitetyin välinein. Yli viisisataasivuisen "mammutin" lähtökohtana ovat hänen lukuisat aikaisemmat julkaisunsa.

Siikala paneutuu tutkimuksessa kansanrunojen kokonaisvaltaiseen haltuunottoon. Lähtökohtana on se, että kalevalaisten laulujen ja loitsujen myytit kuvastavat esittäjiensä ajatusmaailmoja kontekstissaan. Suullisen runouden muotoon puetut ajatusmaailmat saavat sisältönsä ja merkityksensä eri yhteisöissä ja uniikeissa esitystilanteissa, mutta niillä on myös ikivanhat juuret ja paljon yhteisiä nimittäjiä. Yhtenäisen mytologian sijaan mammutti kertookin itämerensuomalaisesta maailmankuvasta ja ajattelutavoista niin aikansa runokulttuurien ja esittäjiensä kuin folkloren kerääjien ja kenttätutkijoiden tuotoksina. Suomen kansan vanhat runot (SKVR, 1908-1948, 1999) ovat tutkimuksen tärkein tutkimusaineisto, rinnalle on nostettu Kansanrunousarkiston tietoja ja virolai- 
sia aineistokokoelmia. Myös vertaileva tutkimus ja kriittinen keskustelu myytteihin ja folkloristiikkaan perehtyneiden tutkijoiden kanssa lukeutuvat tutkimuksen lähteisiin.

\section{MAAILMA JA TRADITIO MYYTTIRUNOJEN YMPÄRILLÄ}

Tutkimuksen alussa Siikala esittelee myyttirunojen keruisiin liittyviä tutkimuksellisia seikkoja, kuten kerääjät, käsitteet ja kansanrunouden merkityksen osana suomalaisen kansallisvaltion rakennusprojektia. Kirja alkaa kertomuksella C. A. Gottlundista, joka helmikuussa 1816 kirjoitti muistiin Juvan pitäjän Ronkaalassa kalevalamittaisen runon Väinemoisen ja Joutavoisen keskinäisestä sanailusta. Tutkijan ja perinteentaitajan kohtaamistilanteesta Juvalla kehkeytyy Siikalalle ominainen tapa tarkastella myyttirunoutta. Myyttirunot ovat tutkimuksessa mytologian ilmentäjiä, genrerajoista riippumatta. Niiden pohjalta syntyvä tulkinta mytologiasta ei sekään ole yhtenäinen kokonaisuus vaan monisärmäinen mosaiikki.

Siikala esittelee taiten sen tradition, joka myyttirunojen keruiden taustalla on Suomessa vaikuttanut. Lisäksi hän selventää, millaisia yleisiä uskonto- ja kulttuuriteorioita kunkin aikakauden kerääät ovat tunnustaneet. Tutkimuksen ansiona pidän sitä, että se kertoo paitsi myyttirunojen maailmoista, myös niistä tekijöistä, joiden pohjalta runokulttuuri ylipäätään on saanut muotonsa. Mammutin yksi ulottuvuus onkin oppihistoriallinen.

\section{RUNOKULTTUURIN MAAILMANJÄRJESTYS}

Erityisen kiinnostavaa luettavaa ovat Siikalan myyttien ja mytologioiden määritelmät. Siikala esittää, että myytti puhuu samaa aikaa montaa eri kieltä. Tästä tosiasiasta syntyy tutkimuksen kiehtovuus:

[Myytti] ei koskaan ole yksimerkityksinen eivätkä sen merkitykset pysy vakiona. Se, miten myyttiset kertomukset, mielikuvat ja metaforat käsitetään erilaisissa kulttuurisissa konteksteissa, vaihtelee. Myyttisen diskurssin luone märittää kuitenkin perinteen uudelleen tuottamisen ja uusiin yhteyksiin sovittamisen mahdollisuuksia. Niinpä myyttiperinne muotoutuu pitkän historian omaavaksi perinteeksi jatkuvasti muunnellenkin. (s. 71.)

Mytologia on Siikalan mukaan kertomus maailmanjärjestyksestä ja sen synnystä, kuitenkin ilman kokonaisvaltaista uskonnollista filosofiaa tai dogmeja. Myyttirunoille puolestaan on ominaista muuntelu, ajan ja paikan rajojen häilyvyys, metaforinen kieli ja aistein havaitsemattoman läsnäolo tulkintatilanteissa. Tästä syystä Siikala ehdottaa luontevasti, että puhuisimme rahvaanuskon ja -uskonnollisuuden yhteydessä mieluummin uskonnollisista maailmoista, joissa ihmiset elävät, kuin uskonnosta, johon hän kytkee institutionaalisuuden ja dogmit. Hän myös valaisee, miten kristinusko pyrki kitkemään rahvaan uskonnollisiin maailmoihin liitettyjä piirteitä. Pyhien ja maagisten paikkojen, 
esineiden ja rituaalien symbolinen haltuunotto on ollut maailmankuvien kohtaamista tyypillisimmillään.

Osana näitä prosesseja ovat eläneet myös runot, itse asiassa koko runokulttuuri. Runojen merkitysten muodostuminen on jatkuva prosessi, ja myyttirunojen kulttuuriset ominaisuudet kehkeytyvät Siikalan tulkinnassa epiikan rooliin ja arvostuksiin yhteisöissään: "Laulajien esittämistä koskeva ihanne ja siihen liittyvä laulajan habitus, esitystilanteessa vakiintunut havaitseminen, käyttäytymisen ja tulkinnan mallit, muotoutuvat erilaisiksi eri alueilla (s. 120)." Samakin runo voidaan tulkita eri tavoin sen mukaan, mikä runoston ja esittäjien suhde on vallitseviin uskonnollisiin maailmoihin ja institutionaalisiin kehyksiin. Runsaat aineistoesimerkit kuvastavat erinomaisesti tätä runokulttuurien piirrettä.

\section{MYYTTI MAAILMAN SYNNYSTÄ}

Maailman syntyyn liittyvistä runokulttuurin variaatioista Siikala kirjoittaa kiinnostavasti. Vertailemalla eri lähteitä hän on löytänyt myös yhteneväisyyksiä. Esimerkiksi komien ja itämerensuomalaisten Maailman muna -myyteissä kirjoitetaan kaikissa alkumerestä, jonka yllä kaarteleva lintu laskeutuu pesimään ja hautomaan munia. Munat kuitenkin vierähtävät mereen, ja rikkoutuneiden munien osista syntyy taivaalle aurinko ja kuu. Näin alkukaaos muuttuu kosmokseksi, josta myyttirunous ja runokulttuurit ovat muovanneet kosmografian, joka kiinnittyy tähtitaivaan kuvioihin ja liikkeisiin. Siikalan mukaan kosmoksen rakennetta koskevat käsitykset kuuluvatkin Euraasian vanhimpaan yhteiseen perinteeseen, ja kosmoksen selittäminen on itämerensuomalaisen myyttirunouden rikkautta.

Siikala on tarkka lähdetekstien lukija, kritisoijakin. Hän muun muassa huomioi tutkijoiden kiinnittäneen niin paljon huomiota miehisten luojaheerosten toimiin ja Sammon ryöstöön liittyviin runoihin, että runo Saaren luomisesta "on merkillisesti unohdettu" (s. 178). Hän esitteleekin yksityiskohtaisesti myyttirunouden jumalat ja sankarit, mutta myös sen, millainen kosmologia itämerensuomalaisen runouden pohjalta hahmottuu. Erityisesti Väinämöistä Siikala pitä luojaheeroksista valtavimpana - ja dominoivimpana.

Tutkimuksen loppupuolella Siikala avaa myyttirunouden konteksteja. Hän selventää, miten myyttirunot kytkeytyvät aina aikansa sosiokulttuurisiin ja taloudellisiin olosuhteisiin, kuten vuodentulon takaamiseen: pyyntiyhteisöjen riistaonneen, paikkaan sitoutuneeseen viljelyyn tai katolisiin pyhiin. Tutkimuksen päättää kokonaisuus runokulttuurista ja mytologian murteista, jossa Siikala esittää tutkimustuloksensa tiivistetysti ja pähkinänkuoressa.

\section{LOPUKSI}

Siikalalle tunnusomaista on passiivissa kirjoittaminen ja tutkijan etäännyttäminen tekstistä. Tämä kertoo, että tekijä on tietyn aikakauden kasvatti, eritoten Martti Haavion ja Matti Kuusen viitoittamaa tietä kulkenut uuttera kerääjä ja tuottelias kirjoittaja. Aivan 
alussa (s. 10) Siikala kertoo, että kirjan taustalla vaikuttava ajatus ihmisten ajatusmaailmojen ja puhumien murteiden perustavanlaatuisista eroista juontuu lapsuuteen, kaupunkilaistytön viettämiin kesiin pohjoissavolaisessa maalaistalossa. Mukana on myös muutama hauska anekdootti nuoren tutkijan Anna-Leena Kuusen kenttätyömatkoilta. Tästä "kerääjän perinnöstä" saamme toivottavasti lukea tulevina vuosina vielä enemmän.

Paikoin teksti on raskasta ja vaikeaselkoista. Lukijalta edellytetään aineistojen ja tradition tuntemusta, joten aivan ensimmäisen vuoden opiskelijalle en mammuttia antaisi luettavaksi. Tekstiin on jäänyt valitettavia typoja ja joitakin oikolukuvaiheen jäänteitä. Nämä jäävät harmittamaan, koska teos kokonaisuutena lunastaa paikkansa samalla jatkumolla, jonne kuuluvat aikaisemmat kansanuskonnollisuuden ja mytologian esitykset Mikael Agricolasta ja Olaus Magnuksesta Martti Haavion Suomalaiseen mytologiaan.

\section{KiRJALLisuUs}

HAAVIO, MARTTI 1965: Suomalainen mytologia. Helsinki: SKS.

\section{Dosentti Outi Fingerroos on akatemiatutkija Jyväskylän yliopistossa.}

